\section{HOOKWORM DISEASE IN MINES OF CALIFORNIA}

HERBERT GUNN, M.D.

Associate Professor of Tropical Medicine, San Francisco Polyclinic, and Post-Graduate Medical School SAN FRANCISCO

The occurrence during the past year of several cases of hookworm disease in miners in California led me, under the auspices of the California State Board of Health, to investigate the subject for the purpose of determining whether or not the infection had become endemic in the mines.

While imported cases of hookworm disease are not infrequently observed in this state, sixty having been reported by me over five years ago, ${ }^{1}$ its occurrence among miners had not previously been noted here. Attention was first drawn to the occurrence of the disease in Jackson, Amador County, by Dr. F. F. Sprague, and later by Dr. E. E. Endicott. Both of these physicians believed that the infection occurred in the adjacent gold-mines, but as the cases observed were all either in persons who had been exposed to infection in other parts of the world or in foreigners of not many years' residence here-Italians, Austrians or Cornishmen-many of whom we know are infected with hookworm before coming to this country, it was necessary to obtain more conclusive evidence before it could be considered that the disease had gained a foothold here. Further, the fact that the disease has not been reported as originating in any mines in the United States, made it appear that we were dealing, in all probability, with imported cases only.

In order to prove conclusively that the disease occurred endemically in a mine it would be necessary to demonstrate the larvæ in the soil from the workings, or to find the disease in a person who had not been exposed to infection elsewhere for at least seven years and preferably ten years. On account of the wandering habits of many of the miners, and the very small number of Americans employed, very few men were available for the purpose of such investigation.

In Mine 1, the results were as follows:

CASE 1.-F., American, native of California, never out of this state; health good except for occasional attacks of abdominal pain, due, it was believed, to chronic appendicitis. Ova of hookworm present; eosinophilia 15 per cent.

CASE 2.-M., American, native of California, never out of state; mining for past two years, always in this mine; health good. Ova of hookworm present; eosinophilia 13 per cent.

CASE 3.-K., nativity not known; not out of California during past forty-eight years; resident of Jackson for last seventeen years; health good except for eruption on leg extending over considerable surface, a typical ground itch. Ova of hookworm present; eosinophilia 12 per cent.

CASE 4.-N., native of England; resident of California for twenty-five years; employed in this mine for fifteen years; according to his own statement health had not been good for some time; shows evidence of moderate anemia. Ova of hookworm pesent in feces; blood not examined.

CASE 5.-L., nativity England; nine years in Jackson; health, according to his own statement excellent; anemia quite apparent, however. Ova of hookworm present; eosinophilia 5 per cent.

CASE 6.-F., Italian; eight years in California; five years in Jackson; unable to work for past five months on account of weakness. Ova of hookworm present; eosinophilia 12 per cent.

Specimens of earth were taken from various parts of the mine where conditions of heat and moisture were

1. California State Jour. Med., April and August, 1905. suitable for the development of the parasite, and in one from a cross-cut at the 1,600-foot level hookworm embryos were demonstrated.

In Mine 2 it was impossible to obtain feces for examination. Larvæ of hookworm were demonstrated in specimens of soil taken from the workings.

In Mine 3 several cases were found, but none had been in California a sufficient number of years to be of any positive value for the purpose of this investigation. No examination was made of the workings of the mine.

\section{EXTENT OF INFECTION}

The men were looked over in mines 1 and 2 after they had finished work, and were bathing anil changing their clothes. Evidence of the disease was everywhere to be seen. The peculiar color of the face, which is so often found in this disease, even when the blood shows but slight reduction in the hemoglobin, was observed quite generally. Quite a number showed moderate anemia, while occasionally it was quite pronounced. It should be borne in mind that we are now considering only those men who were able to work; those so ill that they were unable to work will be referred to later. Several cases of ground-itch were observed, the arms and hands being the most frequently affected parts.

On account of the difficulty of obtaining a sufficient number of stools to form an estimate of the percentage of infected persons in the mines, blood-smears were taken and the eosinophils counted with the following results :

MrNe 1.-Specimens were taken from eighteen miners. Some men were selected who showed evidence of disease. In all examinations 100 cells were counted and Wright's stain, or Oliver's modification of it, was used.

$\begin{array}{cccc}\begin{array}{c}\text { Number } \\ \text { of Patient. }\end{array} & \begin{array}{c}\text { Per cent. of } \\ \text { Eosinophilia. }\end{array} & \begin{array}{c}\text { Number } \\ \text { of Patient. }\end{array} & \begin{array}{c}\text { Per cent. of } \\ \text { Eosinophilia. }\end{array} \\ 1 & 13 & 10 & 13 \\ 2 & 24 & 11 & 21 \\ 3 & 17 & 12 & 9 \\ 4 & 12 & 13 & 10 \\ 5 & 18 & 14 & 18 \\ 6 & 7 & 15 & 3 \\ 7 & 15 & 16 & 20 \\ 8 & 13 & 17 & 11 \\ 9 & 5 & 18 & 12\end{array}$

Number 9 was referred to previously as an infected subject with nine years' residence in Jackson, so that the probabilities are that all of the eighteen are infected, except possibly Number 15, who shows an eosinophilia of 3 per cent. Stools were also obtained from the following on this list and all contained ova of hookworm: Numbers 4, 7, 8, 20.

Feces from eight individuals in this mine showed seven positive. The negative stool came from an assayer whose work until comparatively recently had been entirely above ground. The infection in this mine, it would appear, is close to 90 per cent.

MINE 2.-Men showing evidence of the disease were in some cases selected.
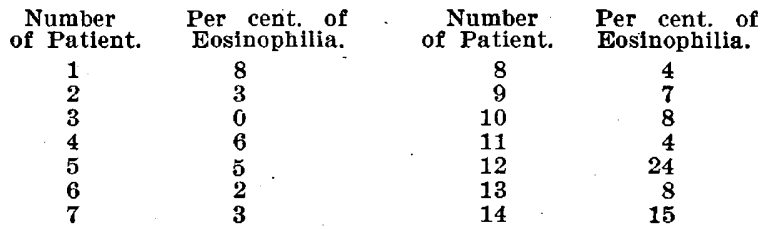

It was impossible to obtain stools from any on this list. The conditions in this mine were very good, there being less moisture throughout most of the workings than in the other mines. Yet from the appearance of the blood, ten out of the fourteen examined, or 70 per cent., should be looked on with suspicion. 
Mine 3.-Blood was taken from the first eleven men who happened along. No selection was made in any case, with the following result:

$\begin{array}{cc}\begin{array}{c}\text { Number } \\ \text { of Patient. }\end{array} & \begin{array}{c}\text { Per cent. of } \\ \text { Eosinophilia. }\end{array} \\ 1 & 5 \\ 2 & 11 \\ 3 & 7 \\ 4 & 14 \\ 5 & 6 \\ 6 & 14\end{array}$

$\begin{array}{cc}\begin{array}{c}\text { Number } \\ \text { of Patient. }\end{array} & \begin{array}{c}\text { Per cent. of } \\ \text { Eosinophilia. }\end{array} \\ 7 & 20 \\ 8 & 14 \\ 9 & 0 \\ 10 & 15 \\ 11 & 5\end{array}$

Here it would appear that all but one are infected, or over 90 per cent. In Number 10 and Number 11, the only ones on this list from whom stools could be obtained, ova of hookworm were found present. Of course it should be remembered in considering the increase in the eosinophils that such might be due to infection with other parasites, but in the examinations of all the stools that could be obtained, evidence of other parasites was generally lacking. In one case Strongyloides stercoralis was present, and in another, Trichocephalus lispar.

CONDITIONS IN THE MINES RELATIVE TO DEVELOPMENT OF THE DISEASE

1. Temperature.-It has been shown that in mines with a temperature below $70 \mathrm{~F}$. the disease makes but little headway. In the mines of Jackson, in portions where the men are working, the temperature is usually kept, by forced draft, below $70 \mathrm{~F}$., but in abandoned portions and adjacent cross-cuts, the only places where a man would be likely to deposit his excrement, the temperature was often as high as 80 or $90 \mathrm{~F}$.

2. Moisture.-A sufficient amount of moisture was found in portions of all of the levels visited.

3. Disposal of Excrement.-Although there are rules in force against the contamination of the workings with feces, it was not very difficult to find evidence that these rules had been broken. The arrangement of tanks in the shafts for the use of the men is open to criticism and is believed to be one of the modes of infection.

\section{ECONOMIC ASPECTS}

There is no question but that the general efficiency of the men is noticeably impaired. At one mine, employing about 300 laborers, it was stated that a reserve of about twenty-five men had to be available to replace those who, on account of sickness, did not appear for work. Many of the men have to take time off now and again to recuperate. Several who were unable to work stated that when they arrived in Jackson they were perfectly strong and well. A large number of these men were encountered on the streets, some of them presenting marked degrees of anemia.

The greatest loss to the mine operators is occasioned by the large number of those moderately affected. In one mine a superintendent who was infected ascribed his somewhat poor physical condition to the results of an illness which occurred a couple of years ago. Another man occupying a responsible position had to be given a vacation every now and then on account of declining health. He presented a quite noticeable anemia, and on examination of the stools, showed a heavy infection. Any number of similar cases could be cited but these examples should be sufficient to show very clearly that the average miner infected with hookworm cannot do the work of a normal man. A loss of 20 per cent. in the efficiency of those infected would be a conservative estimate. That would mean in Mine 2, for instance, where over 300 men are employed at an average of about $\$ 2.50$ per day, estimating the number of those infected as low as 50 per cent., a loss of over $\$ 20,000$ a year.
When it is remembered that nearly 30 per cent. of all deaths in Porto Rico are due to hookworm disease, it is safe to say that directly and indirectly many have died from the infection contracted in these mines.

The danger of the disease being spread in the neighboring valley should be considered, especially as the sanitary arrangements for the disposal of sewage in the town of Jackson are very poor, and as many of the infected miners who are too ill to work in the mines, live on near-by farms until recuperated.

The extent of infection throughout the gold-mines of California can very readily be estimated. The conditions of heat and moisture necessary for the development of the larvæ are more or less the same in all of the mines and all employ the same class of labor. It is believed that it will be found that all of the mines of California are more or less infected, and that probably conditions will approximate those found in Jackson.

The same statement can be made for Virginia City, Nevada. While the mines of Sutter Creek, near Jackson, were not visited, cases which undoubtedly were contracted there were seen. The origin of the infection of the California mines undoubtedly extends back many years. It was probably introduced by laborers from Cornwall, Austria or Italy, in which countries the disease occurs extensively in the mines.

\section{SUMMARY}

It may be stated in summary that:

1. Hookworm disease is endemic in certain mines of California.

2. From 50 to 80 per cent. of those working in these mines are infected.

3. The infection undoubtedly is present in practically all of the gold-mines of California, and in those just over the border of Nevada.

In conclusion I wish to express the belief that hookworm disease is endemic in many mines in various parts of the United States. In many of the so-called cold mines, portions are found where the temperature is constantly high and moisture is present. In all probability most of the mines of this country have been exposed to infection, for in nearly all of them may be found Hungarians, Austrians, Italians or Cornishmen, some of whom are certain to have brought the infection with them from the mines of their countries.

240 Stockton Street.

\section{REPORT OF A CASE OF SPLENIC ABSCESS}

\author{
A. M. FAUNTLEROY, M.D. \\ Surgeon, U. S. Navy \\ WASHINGTON, D. C.
}

This case presented a variety of symptoms which, as far as the spleen itself was concerned, were absolutely negative and it was not until autopsy that a large splenic abscess was discovered. In view of the extreme rarity of this condition and of the lack of symptoms indicating splenic trouble it is believed a full report of the case would be not only instructive but of historical interest.

History--M. P. V., fireman first class, U. S. Navy, was admitted to U. S. Naval Hospital, Philadelphia, March 2, 1910, with a diagncsis of appendicitis. (Case paper No. 67.) The patient was aged 29 years and 2 months, unmarried and denied syphilis; did not use alcohol or tobacco; had always been in robust health, and, about a year previous ts admission, 